Supplement of Atmos. Meas. Tech. Discuss., 8, 12525-12557, 2015

http://www.atmos-meas-tech-discuss.net/8/12525/2015/

doi:10.5194/amtd-8-12525-2015-supplement

(C) Author(s) 2015. CC Attribution 3.0 License.

(c) (1)

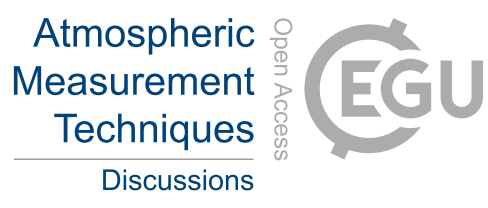

Supplement of

\title{
Re-evaluating the Frankfurt isothermal static diffusion chamber for ice nucleation
}

\section{J. Schrod et al.}

Correspondence to: E. S. Thomson (erik.thomson@chem.gu.se)

The copyright of individual parts of the supplement might differ from the CC-BY 3.0 licence. 
On April 16, 2015 a Saharan dust event was observed at the Taunus Observatory, Mt. Kleiner Feldberg $\left(826 \mathrm{~m} \mathrm{msl}, 50.221879^{\circ} \mathrm{N}, 8.446297^{\circ} \mathrm{E}\right)$. Figures 1 and 2 show the temporal evolution of the dust transport event in six hour increments. In Fig. 1 (a) and (b) the dust layer is primarily west of 5 the Spanish and French coast and by 00 UTC on April 16 (Fig. 1 (c)) dust begins to pervade wide areas of central Europe. Figures 2(d), (e) and (f) confirm that dust is present throughout the entire day, albeit within the RGB product the dust layer is superimposed with cold thick high-level clouds (red) and low-level clouds (yellow) and thus is not always clearly visible.

Figure 3 is the BSC-DREAM8b (vid BSC-DREAM8b ref., and Basart et al., 2012) modeled ver10 tical profile of dust on April 16, 2015 above Taunus Observatory. It highlights that dust was present throughout the day, even in the lowest kilometer of the atmosphere. Thus it is reasonable to conclude that atmospheric samples taken at Taunus Observatory on April 16, 2015 included Saharan dust. Back trajectories from 12 UTC April 16, 2015 computed using HYSPLIT (Draxler and Rolph. 2015; Rolph 2015) and originating from the Taunus Observatory, confirm the observation that the local air mass advanced from the Saharan region (Fig. 4). 
(a) BSC-DREAM8b v2.0 Dust Load $\left(g / \mathrm{m}^{2}\right)$ and $3000 \mathrm{~m}$ Wind

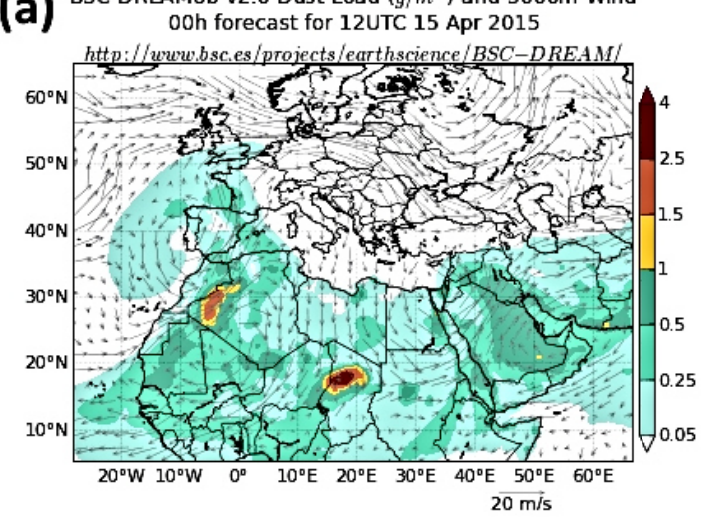

(b) BSC-DREAM8b v2.0 Dust Load $\left(\mathrm{g} / \mathrm{m}^{2}\right)$ and $3000 \mathrm{~m}$ Wind

(b) $06 \mathrm{~h}$ forecast for $18 \mathrm{UTC} 15 \mathrm{Apr} 2015$

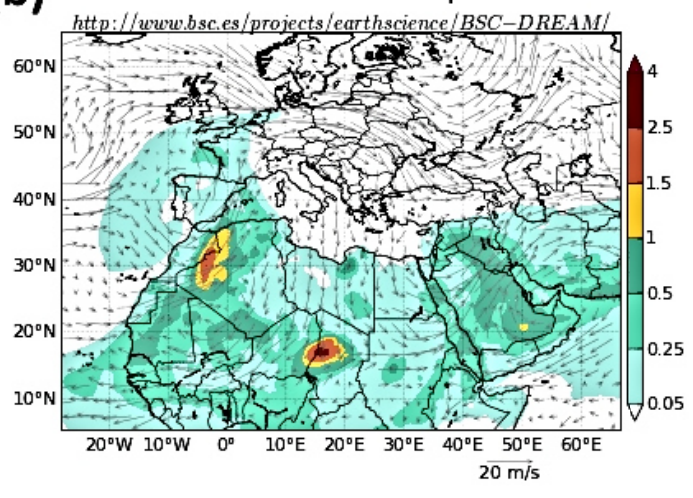

(C) BSC-DREAM8b v2.0 Dust Load $\left(g / \mathrm{m}^{2}\right)$ and $3000 \mathrm{~m}$ Wind (C) $12 \mathrm{~h}$ forecast for OOUTC 16 Apr 2015

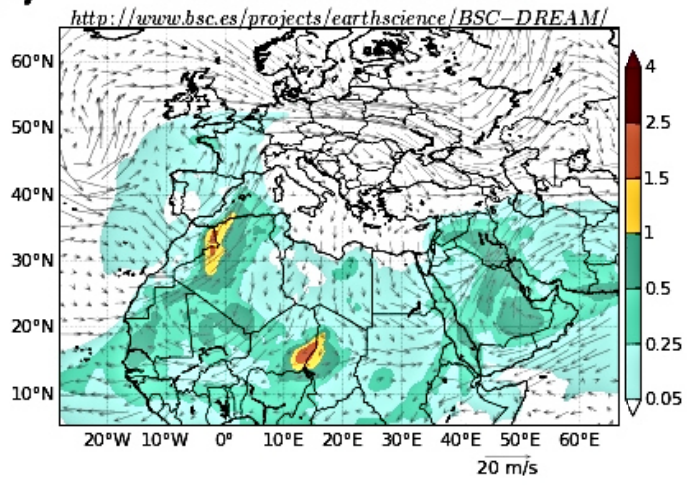

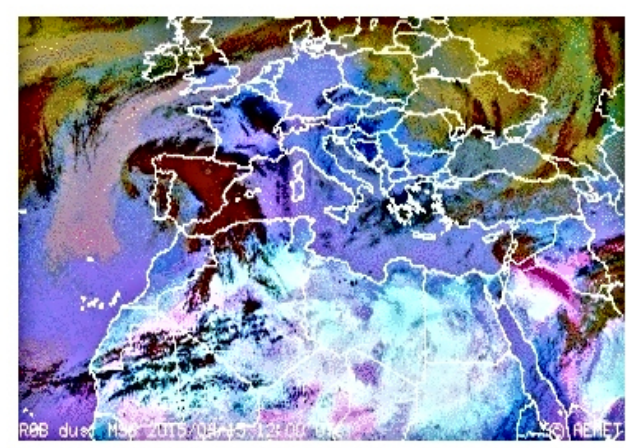
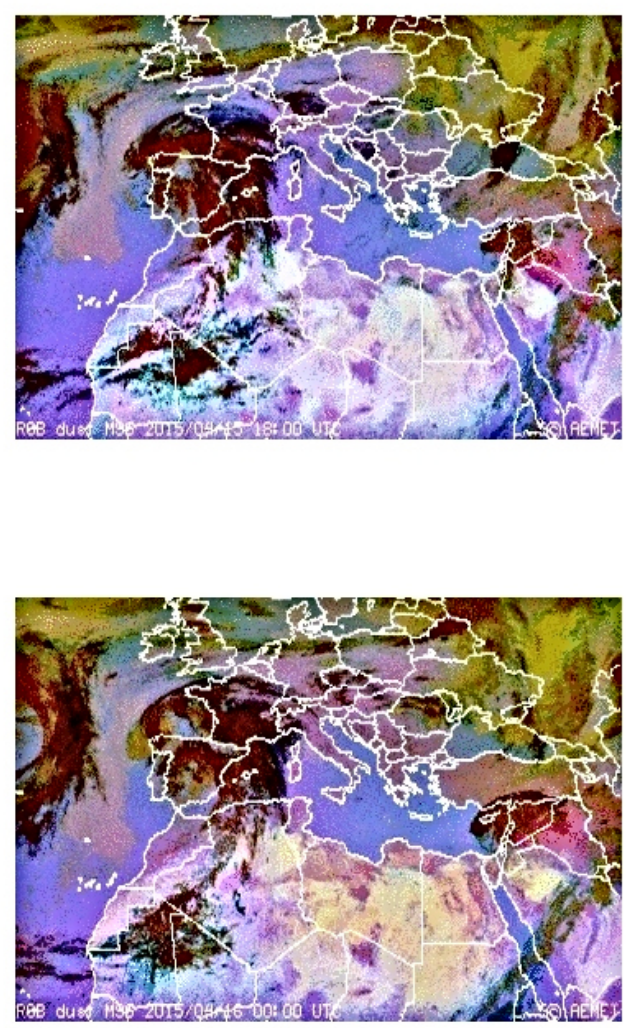

Figure 1. Temporal evolution of the Saharan dust event from (a) 12 UTC April 15, 2015 to (c) 00 UTC April 16, 2015. The lefthand panels show the dust load $\left(\mathrm{g} / \mathrm{m}^{2}\right.$, calculated using BSC-DREAM8b), while the righthand panels show the EUMETSAT RGB dust product, with the intensity of the magenta corresponding to dust intensity. 

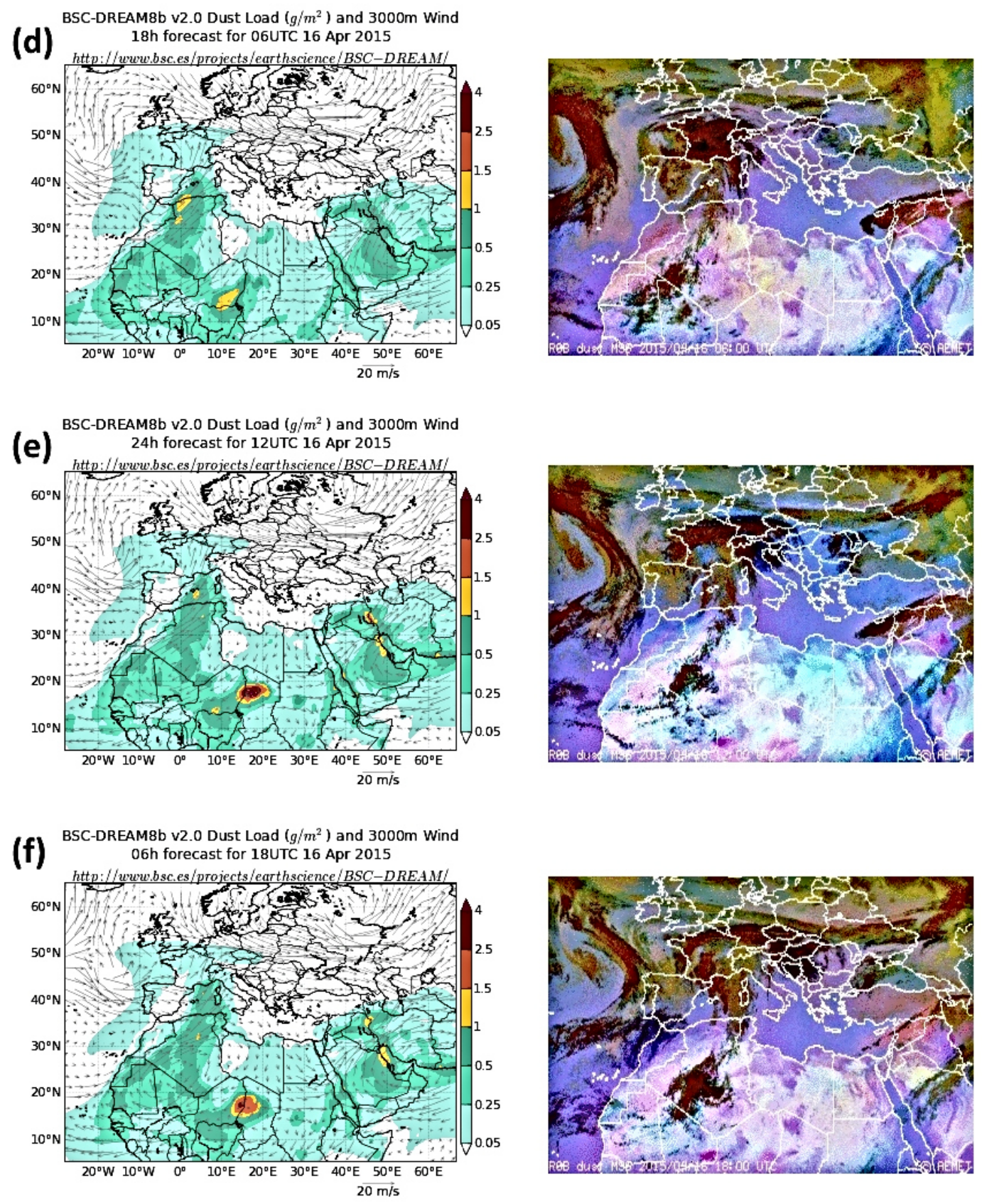

Figure 2. Continuation of Fig. [1]s temporal evolution of the Saharan dust event from (d) 06 UTC April 1, 2015 to (f) 18 UTC April 16, 2015. Again the lefthand panels show the dust load (g/m², calculated using BSCDREAM8b), while the righthand panels show the EUMETSAT RGB dust product, with the intensity of the magenta corresponding to dust intensity. 


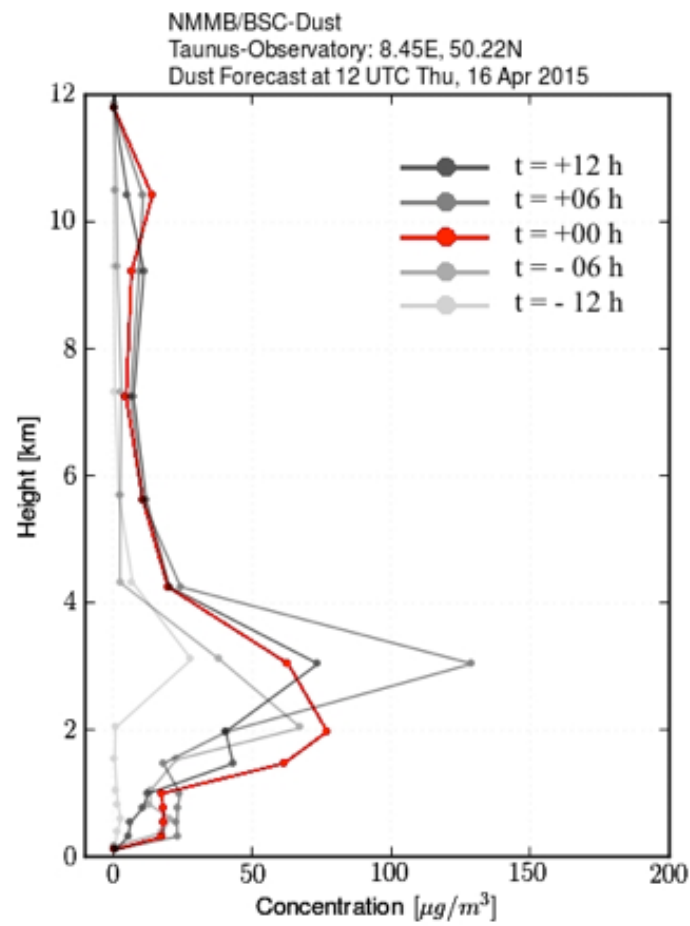

Figure 3. Vertical profile of dust concentration above Taunus Observatory on April 16, 2015 calculated using BSC-DREAM8b

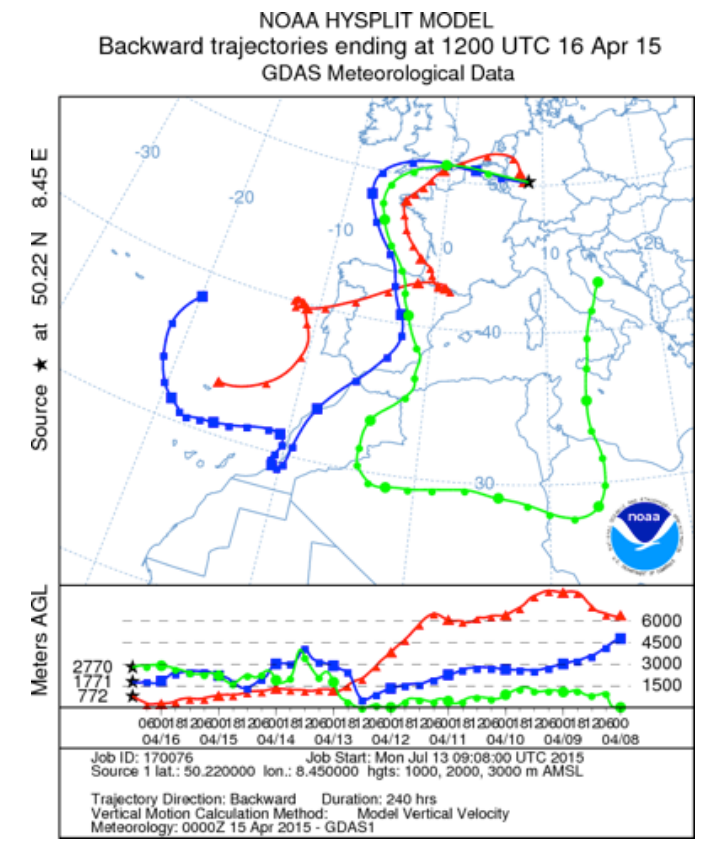

Figure 4. Back trajectories originating from Taunus Observatory at $1000 \mathrm{~m}$ (red), $2000 \mathrm{~m}$ (blue) and $3000 \mathrm{~m}$ (green) amsl. Trajectories were initiated at 12 UTC April 162015 and run for 240 hours. 


\section{References}

Basart, S., Pérez, C., Nickovic, S., Cuevas, E., and Baldasano, J.: Development and evaluation of the BSCDREAM8b dust regional model over Northern Africa, the Mediterranean and the Middle East, Tellus B, 64, 2012.

BSC-DREAM8b: Data and/or images from the BSC-DREAM8b (Dust REgional Atmospheric Model) model, operated by the Barcelona Supercomputing Center (http://www.bsc.es/projects/earthscience/BSCDREAM/).

Draxler, R. R. and Rolph, G. D.: HYSPLIT (HYbrid Single-Particle Lagrangian Integrated Trajectory) Model access via NOAA ARL READY Website (http://ready.arl.noaa.gov/HYSPLIT.php), NOAA Air Resources 25 Laboratory, Silver Spring, MD, 2015.

Rolph, G. D.: Real-time Environmental Applications and Display sYstem (READY) Website (http://ready.arl. noaa.gov), NOAA Air Resources Laboratory, Silver Spring, MD, 2015. 